\title{
THE INFLUENCE OF ATTRACTION, LOCATION, AND SERVICE QUALITY ON REVISIT INTENTION TO SESAOT RURAL TOURISM
}

\author{
Nouria Rahmawati ${ }^{1}$, Lalu Adi Permadi ${ }^{2}$, Baiq Handayani Rinuastuti ${ }^{3}$ \\ ${ }^{1}$ Alumni of Management Bachelor Program, Mataram University, Indonesia. \\ E-mail: nouriarahmawati97@gmail.com \\ 2 Faculty of Economics and Business, Mataram University, Indonesia. \\ E-mail:adipermadi@unram.ac.id \\ ${ }^{3}$ Faculty of Economics and Business, Mataram University, Indonesia. \\ E-mail:hrinuastuti@yahoo.com
}

\begin{tabular}{|c|c|}
\hline ARTICLE INFO & ABSTRACT \\
\hline $\begin{array}{l}\text { Keywords: } \\
\text { Attraction, Location, Service Quality, } \\
\text { Revisit Intention } \\
\text { How to cite: } \\
\text { Rahmawati, N., Permadi., L. Adi., } \\
\text { Rinuastuti.,Baiq Handayani (2021). The } \\
\text { Influence Of Attraction, Location, And } \\
\text { Service Quality On Revisit Intention To } \\
\text { Sesaot Rural Tourism, JMM UNRAM, } \\
\text { 10(1a), 43-57 } \\
\text { DOI: } \\
\text { http://dx.doi.org/10.29303/jmm.v10i1 } \\
\text { A.636 }\end{array}$ & $\begin{array}{l}\text { This study aims to determine Attraction, Location, and } \\
\text { Service Quality influence on Revisit Intention to Sesaot } \\
\text { Rural Tourism Area, Narmada District, West Lombok } \\
\text { Regency, and West Nusa Tenggara. The respondents } \\
\text { were tourists who had visited Sesaot Rural Tourism. } \\
\text { The data collection method is a survey sample with } \\
\text { sampling techniques using purposive sampling with a } \\
\text { total sample of } 100 \text { people-data collection techniques } \\
\text { using questionnaires with data collection tools using } \\
\text { questionnaires that tested validity and reliability. The } \\
\text { analytical technique used is multiple linear regression. } \\
\text { The results showed that the Attraction variable does } \\
\text { not affect Revisit Intention. As for location variables } \\
\text { also do not affect Revisit Intention. On the other side, } \\
\text { service quality affects Revisit Intention. }\end{array}$ \\
\hline $\begin{array}{ll}\text { Dikumpulkan } & : 10 \text { Desember } 2020 \\
\text { Direvisi } & : 2 \text { Januari } 2021 \\
\text { Dipublikasi } & \text { :20 Januari } 2021\end{array}$ & $\begin{array}{l}\text { Penelitian ini bertujuan untuk mengetahui pengaruh } \\
\text { Daya Tarik, Lokasi, dan Kualitas Pelayanan terhadap } \\
\text { Niat Berkunjung Kembali ke Kawasan Wisata } \\
\text { Pedesaan Sesaot, Kecamatan Narmada, Kabupaten } \\
\text { Lombok Barat, dan Nusa Tenggara Barat. } \\
\text { Respondennya adalah wisatawan yang pernah } \\
\text { berkunjung ke Desa Wisata Sesaot. Metode } \\
\text { pengumpulan data adalah sampel survei dengan teknik } \\
\text { pengambilan sampel menggunakan purposive sampling } \\
\text { dengan jumlah sampel sebanyak } 100 \text { orang teknik } \\
\text { pengumpulan data menggunakan kuesioner denganalat } \\
\text { pengumpulan data menggunakan kuesioner yang diuji } \\
\text { validitas dan reliabilitasnya. Teknik analisis yang } \\
\text { digunakan adalah regresi linier berganda. Hasil } \\
\text { penelitian menunjukkan bahwa variabel Daya Tarik } \\
\text { tidak mempengaruhi Niat Berkunjung Kembali. } \\
\text { Sedangkan untuk variabel lokasi juga tidak }\end{array}$ \\
\hline
\end{tabular}

jmm.unram.ac.id 


\begin{tabular}{|l|l|}
\hline $\begin{array}{l}\text { mempengaruhi Niat Berkunjung Kembali. Di sisi lain, } \\
\text { kualitas layanan mempengaruhi Niat Berkunjung } \\
\text { Kembali. }\end{array}$ \\
$\begin{array}{l}\text { Copyright @ 2021. Nouria Rahmawati, Lalu Adi } \\
\text { Permadi, Baiq Handayani Rinuastuti. All rights } \\
\text { reserved. }\end{array}$
\end{tabular}

\section{INTRODUCTION}

The tourism industry is one of the largest industries in the world. The industry contribution is very significant to the countries of the world. That encourages many countries to develop tourism as a primary sector besides other economic sectors such as trade and natural resources, especially for developing countries, including Indonesia.

Based on the law of the Republic of Indonesia No. 10 of 2009, Tourist Attractions are described as everything that has uniqueness, convenience, and value in the form of diversity, natural wealth, culture, and human-made products that are targeted or visited tourists. Tourism Attraction is the primary driver that motivates employees to visit a place. Middleton (2001:122) in Afriza and Abadi (2015) provides the understanding that more profound tourism products are considered a mixture of the three main components of destination offers, namely Attraction, facilities at destinations, and accessibility destinations.

One of the rural tourism destinations in West Nusa Tenggara is Sesaot, located in Narmada District, West Lombok Regency. Sesaot became known firstly in 1980 when the forest opened, and then the dam was constructed. With the Sesaot dam opened, the Aik Nyet area also presented, and later it became a camping group and baths because there are many springs. Along with its development in 1995, the city people have started visiting Sesaot Rural Tourism Area. At that time, the villagers used this to develop tourism in Sesaot Rural Tourism Area. The villagers gradually tried to build facilities such as berugak (Lombok traditional bungalow) and accommodation for visitors in Sesaot. The most visited areas in Sesaot are Petung Hill, bathing pools, forest tours, several waterfalls, and Sesaot Rural Tourism Area sloping park (Ramli, 2020).

The Attraction of the Sesaot Rural Tourism Area lies in the natural springs that come from Mount Rinjani. The calm and fresh air that is still beautiful and avoided pollution makes Sesaot Rural Tourism a favorite visit for the city's people. Nowadays, there is some development in Sesaot, that is swimming pool in Sesaot Rural Tourism. That becomes the top spot for local tourists. They are mainly visiting the place with family. For tourists who want to linger or stay temporarily in Sesaot Rural Tourism, they can stay in one of the destinations, namely in Petung Hill Sesaot Rural Tourism, by providing several lodging packages and equipment with playground attraction, soft tracking, and family camp.

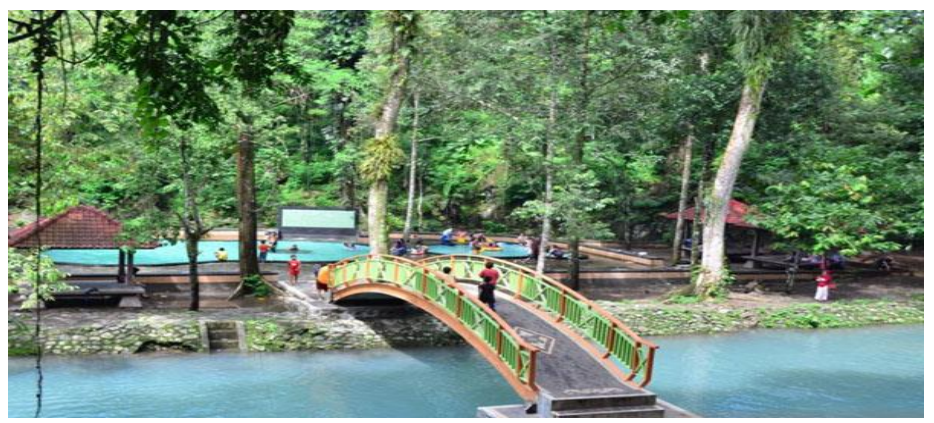


Figure 1.1. Sesaot Pool

Since 2017 the Sesaot Rural Tourism Area tourism was starting its long low seasons. Indications of the problem of a tourist destination are the decrease in the number of tourist visits. Based on 2017 visitor data recorded by the Sesaot Rural Tourism Area Administration, tourist numbers visiting Sesaot Rural Tourism Area were fluctuated (up and down) and, starting at the end of 2017, tend to decrease. The visit of local, national, and foreign tourist numbers from January to December continued to experience ups and downs or dynamic fluctuations.

The problems were continued and compounded by the earthquake in Lombok in 2018. That made Sesaot suffered a significant loss of international and national visitors. The Lombok tourism industry felt the impact of the 2018 earthquake until 2019. Starting 2020 with hope and wish to be better for Lombok, but Covid-19 pandemic came and made all the industry shut down. However, still, Sesaot has the potency and experience to face the big low season. The Attraction of the Sesaot Rural Tourism Area can be used as a determinant factor to attract the tourist to visit the destination. Sulistyan, Ariyono, and Taufiq (2019) stated that Attraction is one factor that influences the tourist interest in revisiting a tourism destination. Koda and Nurlette (2018), Diniyah and Khoirullah (2018), and Marpaung (2019) agreed with Sulistyan, Ariyono, and Taufiq (2019).

Figure 1. Data on tourist visits to Smart Village in 2017

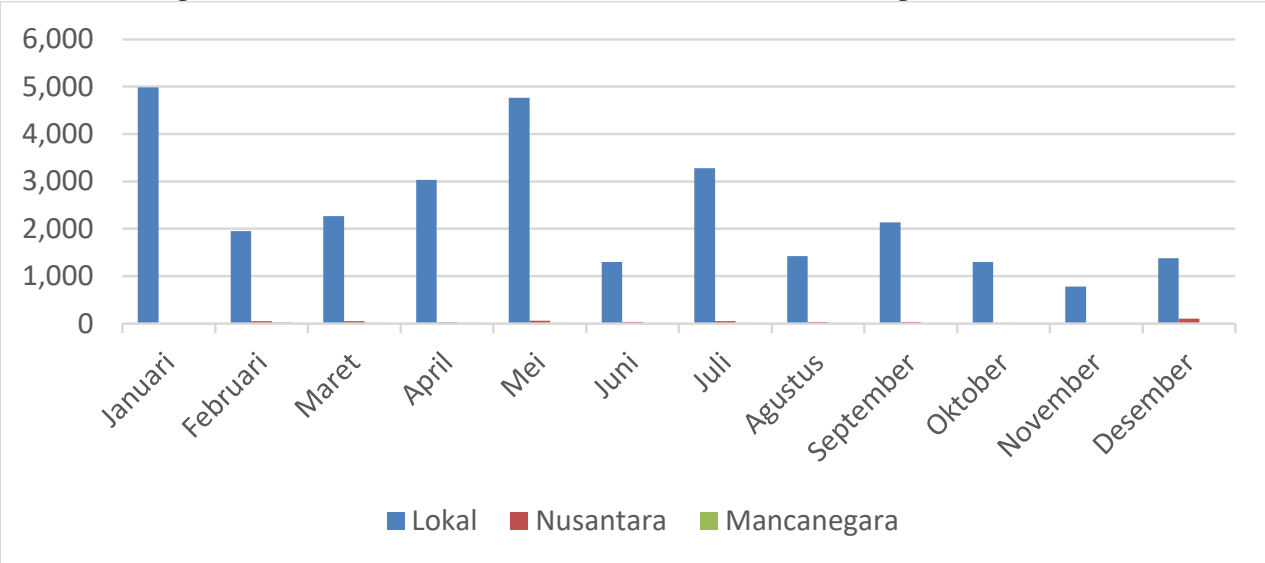

(source: the visitors to the Sesaot Rural Tourism Area Statistic, 2017)

On the other hand, Fatimah (2019) suggested that Location is also a determinant factor that can influence the tourist intention to revisit a destination. Hidayanti and Masyhudi (2020) and Mahfudhotin, Nurfarida, and Hidayat (2020) also advised that Location is vital for visitors when they decide to revisit.

Sesaot has to serve its visitor in service locations like mini restaurants, swimming pools, camping grounds, and traditional food counters as a tourism area. Purnami, Suryawardani, and Suamba (2019) found that the tourism destination's service quality affected customer satisfaction in forming Revisit Intention. That finding confirmed the result of Soleimani and Einolahzadeh (2018), who found that a good service will lead to the revisit intention via customer satisfaction in the tourism industry. Simultaneously, other researchers (Ahlunnazak, 2019; Erica Br Cibro \& Hudrasyah, 2017; Fernaldi \& Sukresna, 2016; Liu \& Lee, 2016; Pujiyati \& Sukaatmadja, 2020) found that the service quality has a direct influence on the revisit intention.

Based on the background above, the study's title is "The Influence of Attraction, Location, and Service Quality On Revisit Intention to Sesaot Rural Tourism". 


\section{LITERATURE REVIEW}

\section{1. $\quad$ Literature Studies}

\subsubsection{Revisit Intention}

According to Miller, Glawter, and Primban in Basiya and Rozak (2012), defining the intention of re-visitation is a person's mental state that reflects a plan to perform some action within a certain period. This definition is assumed to be a direct response to behavior. Its application in researching the definition of revisit interest is that customers will make a repurchase action in the future in direct response to post-purchase behavior within a certain period.

According to Yeti (2005:102) in Rambe (2014), the attributes considered by the community in visiting are:

1. The wisdom of travel products must be sought and liked by the public or following market demand.

2. The wisdom of the price of tourism products is the amount of the price of the components. Price taxation seeks to determine the right price for tourism products to balance the market's purchasing power and attractiveness to prospective tourists.

3. Place/Distribution distribution function presents products in the middle of the market.

4. Promotional mix

5. Services and facilities are significantly related to the elements contained in the service.

\subsection{Relationship Between Variables and Research Hypotheses}

\subsubsection{Relationship of Tourism Attraction and the interest in repeating visit.}

According to Mill \& Morrison (1985), as Karayilan and Cetin (2016) quoted, Attraction is the main decisive element in tourism development in the tourism system. Nguyen Viet, Dang, and Nguyen (2020) stated that Attraction is part of a tourism destination's perceived quality. Some studies also confirmed that tourist Attraction affects the Revisit Intention (Sopyan, 2015; Koda and Nurlette, 2018; Parastiwi and Farida, 2018; Sulastri, Rapini, and Kristiyana, 2018; Marpaung, 2019; Saputro, Sukimin, and Indriastuty, 2020). Base on those studies, the hypothesis can be compiled as follows:

H1: Tourist Attraction affects Revisit Intention to Sesaot Rural Tourism Area.

\subsubsection{Relationship of Location and Tourists Revisit Intention}

Ratnasari and Harti (2016) stated that the Location, along with other variables, affects buying decisions. Firmansyah (2016) and Hidayah (2019) found that Location was a variable that influences customer satisfaction. According to Tjiptono and Chandra (2002), as quoted by Harmen et al. (2017), physical Location requires careful consideration of factors including location access, traffic, spacious parking space, comfortable and safe and environment. If the location access is good, it will guarantee fast access and attract many tourists who come. With easy-to-reach location access and directions to this tourist attraction, there will be tourist visitors' satisfaction. The function of distribution presents the product in the middle of the market. With the presence of products in the middle of the market, the public can easily see and buy them, as measured by access to tourist attractions, the area of Location, and road conditions of tourist Attractions. The visitors must do it carefully.

Mulyati and Afrinata (2018), Fatimah (2019), Hidayanti and Masyhudi (2020), Mahfudhotin, Nurfarida, and Hidayat (2020) conducted research that got results that Location variable influences the Revisit Intention. From the research, the author suspects that there is a relationship between location variables and the Revisit Intention, based on which it compiled a hypothesis as follows:

jmm.unram.ac.id 
H2: Location affects Revisit Intention to Sesaot Rural Tourism .

\subsubsection{Service Quality Relationship with Revisit Intention}

Service Quality is closely related to customer or visitor satisfaction. Service Quality is the key to success, whether or not the Service Quality of goods or services depends on the manufacturer's ability to consistently meet customer expectations (Halim et al., 2021; Wirapraja et al., 2021).

Tjiptono and Chandra (2011), as quoted by Eka, Hamdaini, and Karim (2019), stated that Service Quality is the level of excellence expected and control over these advantages to fulfill the wishes. The quality provided by the company becomes a means of supporting to achieve satisfaction and customer loyalty (Halim et al., 2021; Wirapraja et al., 2021). If there is good service from rural tourism in Rural Tourism, the visitor will feel more treatment. In other words, visitors will be satisfied and come back to the next visit's rural area. Previous studies show that Service Quality affects Revisit Intention (Marpaung, 2019; Nuraen, 2013; Sopyan, 2015; Widiyanto, 2015). So it can be compiled a hypothesis as follows:

H3: The Service Quality affects tourist's Revisit Intention to Sesaot Rural Tourism.

\subsection{Conceptual Design}

This research will determine the influence of variable Attraction, Location, and Service Quality on Revisiting the Rural tourism of Sesaot. Independent variables in this study are Attraction, Location, service quality, and the dependent variable is the revisit intention (Y). Based on variable relationships can compile the conceptual framework as follows: 
Figure 2. Conceptual Design

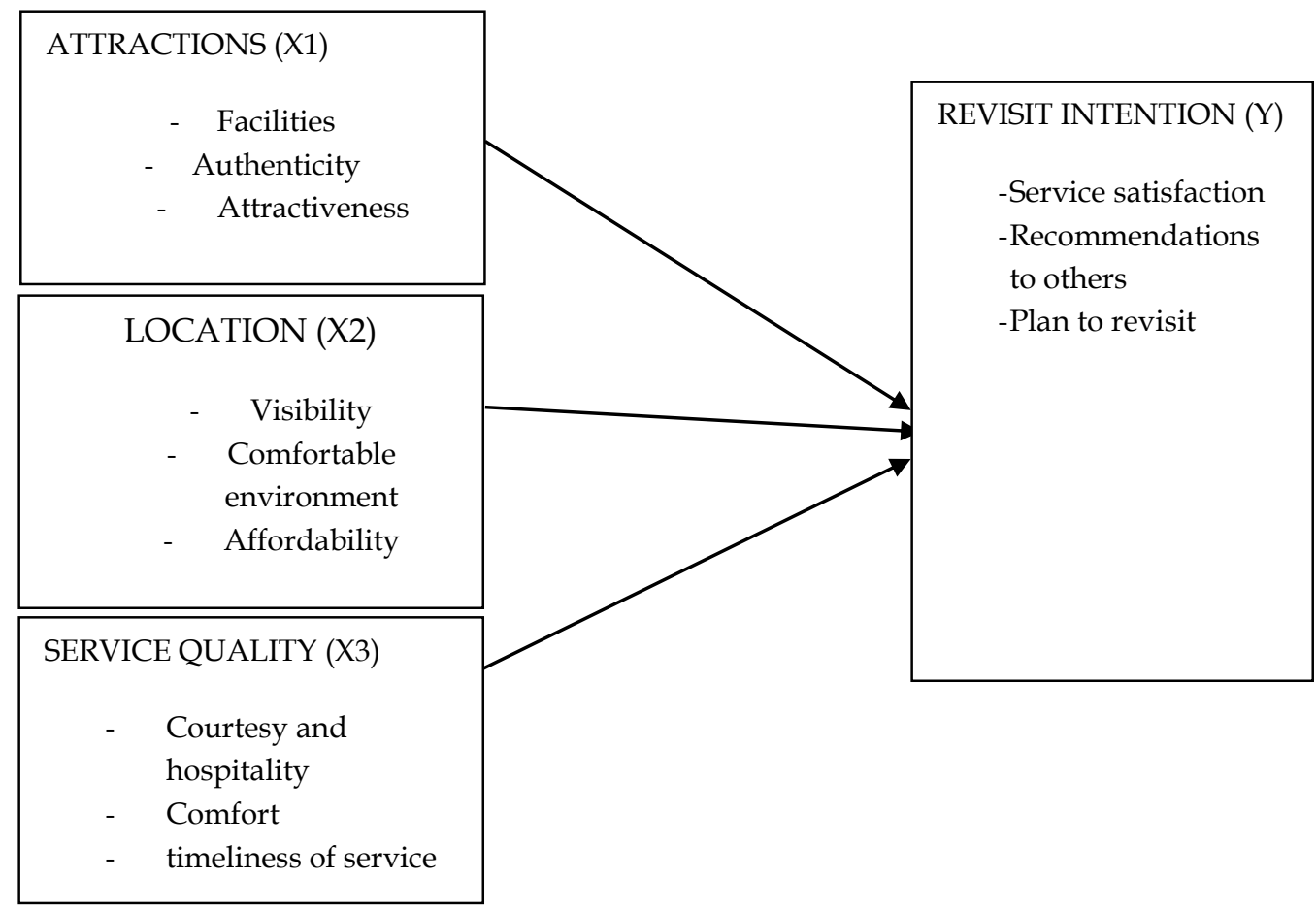

\section{RESEARCH METHOD}

The type of research used in this research is associative research. Associative research aims to know the influence or the relationship between two or more variables. This research has the highest level compared to scripture and comparative because this research can support a theory that can explain, predict, and control a symptom. The independent variables tested are Attraction, Location, and Service Quality. The dependent variable is The Revisit Intention to Sesaot Rural Tourism.

The research site is Sesaot Rural Tourism Area, Narmada District, West Lombok Regency, West Nusa Tenggara. Because Sesaot Rural Tourism Area is an exciting tourist destination and still maintains its authenticity but still doubts its tourism sustainability, there is an opportunity to study the tourism area. The distance from Mataram to Sesaot is about 25-kilometers.

The population in this study is all tourists who have visited Sesaot and are interested in revisiting Sesaot. Given the large population, the data collection method used is a survey sample. Survey samples are data collection conducted only on a portion of the population members. According to Roscoe (as quoted by Sekaran \& Bougie, 2016), in the withdrawal of the number of sample sizes, if the population is not known for specific amounts, then the number of eligible sample members is 30 to 500. In this study, the researcher used 100 samples.

Sampling techniques are non-probability sampling because the identification of unknown populations, in this case, is purposive sampling, which is a technique of determining samples with specific considerations or criteria. Participating respondents are the tourists who had come to Sesaot and revisit intention, aged 15 years and over, with a visiting period from February to April 2020. 
The data collection technique in this study is Interview. Questionnaires and Observations. The data collection tool used is a questionnaire. A questionnaire is a set of questions that researchers have prepared to obtain the required data. Questions asked regarding the Attraction, Location, Service Quality, and Revisit Intention to Sesaot Rural Tourism Area. The measurement scale used is the Likert scale. Data types in this research are quantitative data and qualitative data. The Data Source is primary data and Secondary Data. The operational definition of the variables are

1. Attraction (X1)

In this research, what is meant in the Attraction is everything that becomes the Attraction of Sesaot Rural Tourism to attract people to visit. In this case, the indicators are facilities, authenticity, and attractiveness.

2. Location $(\mathrm{X} 2)$

In this research, the Location of Sesaot Rural Tourism conveys to tourists where the Location of Sesaot Rural Tourism is strategic so that it is easy to reach and makes it easier for tourists to visit again. Indicators used in this study include visibility, comfortable environment, affordability.

3. Service Quality (X3)

In this research, the Service Quality is the Service Quality of various Sesaot Rural Tourism options both received directly and indirectly by tourists. Tourists in Sesaot Rural Tourism are very polite, friendly villagers and traders who provide good service to visitors to feel at home and want to revisit. In this case, the indicators are politeness and hospitality, comfort, punctuality of service.

4. Revisit Intention ( $\mathrm{Y})$

Revisit intention in this research will define a series of elements that reflect tourists' intention to visit back to the Tourist Attraction of Sesaot Rural Tourism Area. In this case, the indicators are service satisfaction, recommendations to others, revisit planning.

Validity indicates how far a test or a test of those operations measures what should be measured. An instrument is said to be valid when it can measure what is measured. Validation test using Person correlation analysis showed that significantly each instrument on the variable Attraction (X1), Location (X2), service quality (X3), and Revisit Intention (Y). $\mathrm{R}$-value calculated greater than $\mathrm{r}$ table of 0.195 . That shows each instrument of the direct evidence variable is valid, and then all items can be used as regression processing data.

Reliability measurement is a tool to measure a questionnaire that is the indicator of a variable. A questionnaire is reliable or reliable if the answer to a question is consistent or stable over time (Ghozali,2007 as quoted by Marlindawati and Indriani, 2016). Reliability measurement shows that each variable represents a reliable data result with the coefficients of alpha reliability $0.99(\mathrm{X} 1), 0.872(\mathrm{X} 2), 0.875(\mathrm{X} 3)$, and $0.953(\mathrm{Y})$ so that the entire instrument in this study is feasible to collect data.

Multiple linear regression tests determine how much the free variables tested can affect the shift in value on bound variables. In general, observation data $Y$ formed by formula (Simamora,2005 as quoted by Mustaqim, 2014) :

$\mathrm{Y}-\mathrm{a}+\mathrm{b} 1 \mathrm{X} 1+\mathrm{b} 2 \mathrm{X} 2+\mathrm{b} 3 \mathrm{X} 3+\mathrm{e}$

Description:

$\mathrm{Y}=$ Revisit Intention, $\mathrm{a}=$ Constant, $\mathrm{b}=$ Regression coefficient, $\mathrm{X} 1=$ Attraction, $\mathrm{X} 2=$ Location, X3= Service Quality, e= Standard error

Later, the researchers used a partial test (t-test) test to see the significance of individual free variables' influence on bound variables by assuming other free variables were constant. Then $\mathrm{F}$ test was conducted to see if the model analyzed had a high degree of the model's feasibility, i.e., the variables used could explain the internalized phenomena.

jmm.unram.ac.id 
After implementing the research methods, in the survey phase, the respondent's characteristics that founded are demographic characteristics. The following is an exposure to a description of respondents' responses to each variable studied. The age of respondents ranged from 15 years to 30 years. Respondents at the age of 20-24 years more dominant than others because at that vulnerable age, most people are more often vacation or visit tourist attractions in various areas because they still have much free time, and most people use it by visiting various tourist areas. Most of the respondents are bachelor educated.

The dominant respondents were students (58\%) who more often pampering themselves. They were not experiencing the saturation of their activities. However, they get some college assignments that must be completed or want to do field studies related to tourism while refreshing and more time to gather with friends, relatives so that it becomes a reason to travel.

Table 1. Respondents By Income

\begin{tabular}{|l|l|l|l|}
\hline No & Income & Amount & Percentage (\%) \\
\hline 1 & $<\operatorname{Rp~500.000}$ & 52 & $52 \%$ \\
\hline 3 & $\operatorname{Rp~500.000-1.000.000~}$ & 29 & $29 \%$ \\
\hline 4 & $>\operatorname{Rp} 1.000 .000$ & 19 & $19 \%$ \\
\hline \multicolumn{2}{|l|}{ TOTAL } & 100 & $100 \%$ \\
\hline
\end{tabular}

Source: Data processing results

Based on table 1, the percentage of visitors based on the highest income level is $<R p$ 500,000 , which amounts to 52 respondents or a $52 \%$ percentage with more percentage than other respondents' income. Respondents with this income showed that visitors to the Sesaot Rural Tourism have a low-income level. Alternatively, maybe a large number of visitors are visitors from the lower middle class, so they choose a tourist Attraction that is cheap and fits the income. Then the respondents with an income of Rp500,000-1,000,000 amounted to 29 respondents or a percentage of $29 \%$, and lastly, respondents with income $>1.000 .000$ as many as 19 respondents or a percentage of $19 \%$ also have confidence that traveling to Sesaot Rural Tourism creates a comfortable atmosphere to visit and save expenses with minimum service standards needed in the provision of existing facilities and infrastructure.

\section{DISCUSSION OF THE ANALYSIS OR RESULTS}

\subsection{Results}

The multiple linear regression analysis test results presented in the table below:

Table 2. Multiple Linear Regression Analysis Results

\begin{tabular}{|c|c|c|c|c|c|c|}
\hline \multicolumn{7}{|c|}{ Coefficients } \\
\hline \multicolumn{2}{|c|}{ Model } & \multicolumn{2}{|c|}{$\begin{array}{l}\text { Unstandardized } \\
\text { Coefficients }\end{array}$} & \multirow{2}{*}{\begin{tabular}{|l} 
Standardize \\
d \\
Coefficients \\
Beta
\end{tabular}} & \multirow[t]{2}{*}{$\mathrm{T}$} & \multirow[t]{2}{*}{ Sign } \\
\hline & & B & Std. Error & & & \\
\hline \multirow[t]{4}{*}{1} & (Constant) & 3.803 & 1.457 & & 2.611 & .010 \\
\hline & Attraction & -.171 & .116 & -.200 & -1.474 & .144 \\
\hline & Location & -.085 & .122 & -.106 & -.695 & .488 \\
\hline & Service Quality & .756 & .124 & .927 & 6.113 & .000 \\
\hline \multicolumn{4}{|c|}{ a. Dependent Variable: Interest in R-Visit } & & & \\
\hline
\end{tabular}

SPSS Output Source 16 primary data processing

Based on the table above, multiple linear regression equations obtained as follows: jmm.unram.ac.id 


$$
\mathrm{Y}=3,803-0.171-0.085+0.756+\mathrm{e}
$$

Constant value $\alpha=3,803$; this means that if the value of free variable consisting of (attraction, location, and service quality) equal to zero value, then the amount of variable bound (interest return) 3,803.

The regression coefficient of the attraction variable (X1) is -0.171 , meaning that if another independent variable value fixed and the Attraction (X1) is $1 \%$, then the return interest $(Y)$ will decrease by 0.171 . The negative value coefficient means an opposite influence between (X1) and (Y). The more the Attraction (X1), the less Revisit Intention (Y).

The location variable regression coefficient (X2) of -0.085 means that if another independent variable has a fixed value and the location variable increases by $1 \%$, interest in revisit will decrease by 0.085 . A coefficient of negative value means a counter-influence between (X2) and (y). So, the higher the Location affordable to the tourists, the less interest in repeating visits.

The regression coefficient of the service quality variable (X3) of 0.756 means that if other independent variables have a fixed value and service quality increases by $1 \%$, then the interest in revisit $(\mathrm{Y})$ will increase by 0.756 . The coefficient of positive value means a direct influence between the Service Quality and the interest in re-visitation. The better the Service Quality, the more visits are repeated.

This research aimed to prove the influence of free variables on bound variables, namely the influence of Attraction (X1), Location (X2), service quality (X3) on the intention of revisiting.

To test the hypothesis, the researcher was using a t-test. The results of the t-test show that the influence of free variables on bound variables. Basic decision making refers to the calculation of $t$ calculate $>t$ table and the significant value of each variable $<0.05$

Table 3. Test Result t

\begin{tabular}{|l|c|c|c|}
\hline Variable & $\begin{array}{c}\text { Cofisien } \\
\text { regression }\end{array}$ & $\mathfrak{t}_{\text {count }}$ & $\begin{array}{c}\text { Significance } \\
\text { value }\end{array}$ \\
\hline Attraction & -200 & -1474 & 0,144 \\
\hline Location & -106 & -695 & 0,488 \\
\hline Service quality & 927 & 6113 & 0,000 \\
\hline
\end{tabular}

Source: Primary data 2020

1. First hypothesis testing (H1)

Statistical results from the t-test for the Attraction variable obtained the $\mathrm{t}$-value of 1474 with a significance level of 0.0144 because the significance value is more significant than $0.05(0.0144>0.05)$, the regression coefficient is negative. At -200 , the hypothesis stating that "the better the Attraction, the better the interest in repeating visit." is rejected.

2. Second Hypothesis Testing (H2)

Statistical value for $t$-test on location variable obtained $t$ calculated value of -695 with significance rate of 0.488 because the significance value is more significant than 0.05 $(0.488>0.05)$ and regression coefficient is the negative value of -106 the hypothesis stating that "the better the location then, the better the Intention of tourists returning to sesaot" tourist village is rejected.

3. Third Hypothesis Test (H3)

Statistical results from the t-test for service quality variables obtained a calculated $t$ value of 927 with a significance of 0.000 because the value of greater significance is smaller than $0.05(0.000>0.05)$, and the regression coefficient is positive. Amount 6113 , the hypothesis states that "the better the Service Quality, the better the Intention of tourists visiting back to the tourist village sesaot" received 
The $\mathrm{F}$ test aimed to see if the model analyzed had a high degree of the model's feasibility, i.e., the variables used to explain the internalized phenomena. Data of $\mathrm{F}$ test results against the data used in this study will be in table 4 .

Table 4. Test Result $\mathrm{f}$

\begin{tabular}{|c|c|c|c|c|c|c|}
\hline \multicolumn{7}{|c|}{ ANOVA } \\
\hline \multicolumn{2}{|c|}{ Model } & $\begin{array}{c}\text { Sum of } \\
\text { Squares }\end{array}$ & Df & \begin{tabular}{|l} 
Mean \\
Square
\end{tabular} & $\mathrm{F}$ & S \\
\hline \multirow[t]{3}{*}{1} & on $\quad$ Regressi & 618.050 & 3 & 206.017 & 29.31 & $.000^{\mathrm{a}}$ \\
\hline & Residual & 674.700 & 96 & 7.028 & & \\
\hline & Total & 1292.750 & 99 & & & \\
\hline \multicolumn{7}{|c|}{ a. Predictors: (Constant), Service Quality X3, Attraction X1, Location X2 } \\
\hline & Dependent Val & riable: Interest in & $e-V i$ & & & \\
\hline
\end{tabular}

Source: SPSS output 16 primary data processing 2020

Based on the table and curve above, it appears that F calculates 29.313 with a significant probability of 0.000 , which means a significant probability value because $<0.05$. Simultaneously, the F table result with $\mathrm{df} 1=3$ ndan $\mathrm{df} 2=96$ at $\mathrm{a}=0.05$ is 2.70 (for table $\mathrm{F}$ can be seen in the attachment). It is mean F calculate $>\mathrm{F}$ table $(29.13>2.70)$.

Based on the table and curve above, all independent variables (Attraction, Location, and Service Quality) are feasible to explain the internalized dependent variables.

Table 5. Determination Coefficient Test Results

\begin{tabular}{|r|c|c|c|c|}
\hline \multicolumn{5}{|c|}{ Model Summary } \\
\hline $\begin{array}{r}\mathrm{M} \\
\text { odel }\end{array}$ & $\mathrm{R}$ & R Square & $\begin{array}{c}\text { Adjusted } \\
\text { Square }\end{array}$ & $\begin{array}{c}\text { Std. The error } \\
\text { of the Estimate }\end{array}$ \\
\hline 1 & $.691^{\mathrm{a}}$ & .478 & .462 & 2.65106 \\
\hline
\end{tabular}

a. Predictors: (Constant), Service Quality X3, Attraction X1, Location X2

Source: SPSS output 16 primary data processing

Based on the coefficient test determination above, the value of $r$ square of 0.478 or 47.8\% means Attraction, Location, and Service Quality influence to the dependent variable was $47.8 \%$. In comparison, the influence of other free variables outside the research variables to revisit Sesaot was $52.2 \%$.

\subsection{Discussions}

Table 6. Research Results

\begin{tabular}{|l|l|l|l|l|}
\hline No & \multicolumn{1}{|c|}{ Hypothesis } & \multicolumn{1}{|c|}{ B } & Significance & \multicolumn{1}{|c|}{ Conclusion } \\
\hline 1 & $\begin{array}{l}\text { the Attraction affects } \\
\text { the Revisit Intention } \\
\text { to Sesaot Rural } \\
\text { Tourism }\end{array}$ & $-0,200$ & 0,144 & $\begin{array}{l}\text { Negative and } \\
\text { insignificant }\end{array}$ \\
\hline 2 & $\begin{array}{l}\text { location affects the } \\
\text { Revisit Intention to } \\
\text { Sesaot Rural Tourism }\end{array}$ & $-0,106$ & 0,488 & $\begin{array}{l}\text { Negative and } \\
\text { insignificant }\end{array}$ \\
\hline
\end{tabular}




\begin{tabular}{|l|l|l|l|l|}
\hline 3 & $\begin{array}{l}\text { the Service Quality } \\
\text { affects the Revisit } \\
\text { Intention to Sesaot } \\
\text { Rural Tourism }\end{array}$ & 0,927 & 0,000 & $\begin{array}{l}\text { Positive and } \\
\text { significant }\end{array}$ \\
\hline
\end{tabular}

\subsubsection{The Effect of Attraction on Revisit Intention}

Based on the study results, Attraction of Sesaot Rural Tourism has a high value by the visitors. The data showed that most respondents rated in a high category. However, hypothesis 1, "Attraction affects Revisit Intention ", was rejected after tested. These results showed that the Attraction of the Sesaot Rural Tourism could not influence the Revisit Intention. However, the Attraction in Sesaot Rural Tourism is highly valued by the visitors, not yet maximal in managing the potential contained in Sesaot Rural Tourism. This result is confirmed by one of the higher rank officers in the West Nusa Tenggara Culture and Tourism Agency, who stated that Sesaot's Attraction is very dependent on water from Mount Rinjani and Rainy Season, it is hard to offer it to the tourists outside of Rainy Season. This result does not confirm the previous result (Abror, 2019; Nabila \& Widiyastuti, 2017; Parastiwi \& Farida, 2018; Widiyanto, 2015; Yusendra \& Paramitasari, 2018)

\subsubsection{The Effect of Location on Revisit Intention}

On descriptive analysis, the Sesaot Rural Tourism Location has a good rank. The data showed that most respondents rated in suitable categories. The study results obtained hypothesis 2 that the virtuous "location affects the revisit Intention " was rejected. It shows that Sesaot Tourism Location is not an influence of the intention of revisiting. Respondents $X$ confirmed this by stating that accessibility between the tourism spots of Sesaot were not connected. This study's results are not in line with previous research (Bachtiar \& Arif Wibowo, 2016; Hidayanti \& Masyhudi, 2020; Mulyati \& Afrinata, 2018).

\subsubsection{The Effect of Service Quality on Revisit Intention}

In the descriptive analysis, the Service Quality has a good category. The data showed that many respondents gave value in good categories, which means that the Service Quality significantly influences tourists' intention to revisit Sesaot. It also proves that the Service Quality provided by the Sesaot is quite reasonable that visitors want to make a revisit. From the above results, Service Quality plays a vital role in achieving quality results. The better the Service Quality provided to visitors, the better the interest to revisit Sesaot Rural Tourism. There is a positive and significant influence between the variable Service Quality to the interest of revisiting the tourism village of Sesaot. This study's results are in line with previous research conducted by Sopyan (2015); Sulastri, Rapini, and Kristiyana (2018); Saputro, Sukimin, and Indriastuty (2020).

\section{CONCLUSION AND SUGGESTIONS.}

\subsection{Conclusions}

Based on the results of the research and discussion, the conclusions are as follows:

1. The Attraction has an insignificant effect on the Revisit Intention to Sesaot Rural Tourism, meaning that the Attraction owned by Sesaot Rural Tourism is currently unable to influence tourists' Revisit Intention.

2. The Location has an insignificant effect on the Revisit Intention to Sesaot Rural Tourism, meaning that Location indicators such as easy to reach, strategic Location, and road conditions do not affect tourists' Revisit Intention.

3. The Service Quality has a positive and significant effect on the Revisit Intention to Sesaot Rural Tourism, meaning that the better the Service Quality provided by the surrounding community, the more tourists visit again. 


\subsection{Suggestions}

The Sesaot Rural Tourism Area Administration needs to anticipate the future by preparing its plan and current operational location management. In the village plan, three things needed to consider. First, preserve the main Attraction of Sesaot, that is, nature. Second, it prepares connectivity between spots in the Sesaot Rural Tourism and another place, such as the provincial capital city and other rural areas. Third, preparing local tourism human resources to be ready for high quality serving the tourist by bringing third-party cooperation. For example, the village administration and local higher education work together to create hospitality training. In this way, what is to be done with the tourism area becomes apparent, and sustainable rural tourism in the Sesaot Rural Tourism Area is complete.

For villagers in the Sesaot tourism sites, they should work together with the local government of Sesaot Rural Tourism Area to create useful services and sustainable tourism by memorizing these seven safe, orderly things, beautiful, peaceful, and memorable.

Based on this study results, if the further researchers want to raise the same theme, they are advised to look for and use other factors that can influence the interest in revisits a rural tourism area. In addition to using questionnaires, the current result recommends using qualitative methods and in-depth interview techniques to complete the data obtained.

\section{Acknowledgements}

Thank you for all great people for supporting us: families, friends and co-workers, our great lecturers and professors. Thank you for Mataram University and Management Department Faculty of Economics and Business Mataram University. 


\section{REFERENCES}

Abror, A. (2019). The Influence of E-Wom and Image Destination on Revisit Decision Moderated by Trust: A Literature Review.

Afriza, L., \& Abadi, H. (2015). Pengaruh Atraksi Pariwisata Terhadap Pemberdayaan Masyarakat Di Pantai Cimaja Cikakak Sukabumi. Tourism Scientific Journal, 1(1), 85. https://doi.org/10.32659/tsj.v1i1.6

Ahlunnazak, A. I. (2019). The Iinfluence Of Electronic Word-Of-Mouth, Service Quality, Destination Image And Satisfaction Toward Revisit Intention (Vol. 2, Issue 2).

Bachtiar, M. L., \& Arif Wibowo, M. (2016). Pengaruh Strategi Bauran Pemasaran Terhadap Minat Berkunjung Kembali Di Objek Wisata Pantai Kabupaten Gunungkidul (Studi Pada Mahasiswa Strata 1 Fakultas Ekonomi Universitas Negeri Yogyakarta). Jurnal Manajemen Bisnis Indonesia, 5(1), 40-49.

Diniyah, F., \& Khoirullah, K. (2018). Pengaruh Daya Tarik Wisata Terhadap Minat Kunjungan Ulang Wisatawan di Museum Benteng Vredeburg Yogyakarta.

Eka, D., Hamdaini, Y., \& Karim, S. (2019). Kualitas Pelayanan Fakultas Ekonomi Universitas Sriwijaya. Jurnal Manajemen Dan Bisnis Sriwijaya, 16(2), 89-98. https://doi.org/10.29259/jmbs.v16i2.6948

Erica Br Cibro, Y., \& Hudrasyah, H. (2017). Factors That Influence Customer's Intentions To Revisit Cafe: Case Study Of Siete Café In Bandung. In Cibro and Hudrasyah / Journal of Business and Management (Vol. 6, Issue 2).

Fatimah, S. (2019). Analisis Pengaruh Citra Destinasi Dan Lokasi Terhadap Minat Berkunjung Kembali. Majalah Ilmiah Bahari Jogja, 17(2), 28-41. https://doi.org/10.33489/mibj.v17i2.207

Fernaldi, E. H., \& Sukresna, M. (2016). Analisis Pengaruh Faktor Evaluatif Wisatawan Terhadap Minat Berperilaku Di Masa Depan, Dengan Kepuasan Sebagai Variabel Intervening (Studi Pada Tempat Wisata Alam Umbul Sidomukti Semarang). Diponegoro Journal of Management, 6(1), 1-12. http://ejournals1.undip.ac.id/index.php/dbr

Firmansyah, A. (2016). Pengaruh Lokasi, Harga, Fasilitas, dan Kualitas Pelayanan terhadap Kepuasan Konsumen. 1-14.

Halim, F., Zukhruf, A., Kurniullah, K., Butarbutar, M., Efendi, E., Sudarso, A., Purba, B., Lie, D., Sisca, S., Simarmata, H. M. P., Permadi, L. A., \& Novela, V. (2021). Manajemen Pemasaran Jasa. In R. Watrianthos (Ed.), Yayasan Kita Menulis (1st ed., Vol. 1, Issue 1). Yayasan Kita Menulis.

Harmen, H., Agustini, F., Harahap, L. M., \& Amanah, D. (2017). Analysis of Factors Influencing the Visitor Satisfaction on Pantai Cermin, Indonesia. IOSR Journal of Business and Management, 19(06), 47-53. https:/ / doi.org/10.9790/487x-1906024753

Hidayah, N. (2019). Pengaruh Harga, Fasilitas, Pelayanan, Dan Lokasi Terhadap Kepuasan Pelanggan Pada Rumah Makan Di Kabupaten Bulukumba. In UIN Alaudin Makassar (Vol. 53, Issue 9).

Hidayanti, A. A., \& Masyhudi, L. (2020). Pengaruh Electronic Word Of Mouth, Daya Tarik Dan Lokasi Terhadap Minat Berkunjung Wisatawan Di Desa Tete Batu Kabupaten Lombok Timur. 22(7), 117-122.

Karayilan, E., \& Cetin, G. (2016). Tourism Destination: Design of Experiences. In The Handbook of Managing and Marketing Tourism Experiences. https://doi.org/10.1108/9781786352897

Koda, M. C., \& Nurlette, N. K. S. (2018). Pengaruh Daya Tarik Wisata Terhadap Minat Kunjungan Ulang Wisatawan. https://doi.org/10.31227/osf.io/uk87h

jmm.unram.ac.id 
Liu, C. H. S., \& Lee, T. (2016). Service quality and price perception of service: Influence on word-of-mouth and revisit intention. Journal of Air Transport Management, 52, 42-54. https://doi.org/10.1016/j.jairtraman.2015.12.007

Mahfudhotin, S., Nurfarida, I. N., \& Hidayat, C. W. (2020). Analisis Pengaruh Citra Destinasi, Lokasi Dan Media Sosial Terhadap Minat Berkunjung Kembali Di Objek Wisata Kampoeng Heritage Kajoetangan Malang. Journal Riset Mahasiswa Manajemen (JRMM), 6(2), 1-6.

Marlindawati, M., \& Indriani, P. (2016). E-Learning Dengan Penerapan Model End Using Computing Satisfaction ( EUCS ) (Studi Kasus : Universitas Bina Darma dan STMIK MDP ). Jurnal Ilmiah MATRIK, 18(1), 55-66.

Marpaung, B. (2019). Pengaruh Daya Tarik, Kualitas Pelayanan, Fasilitas Dan Keselamatan Dengan Kepuasan Wisatawan Sebagai Variabel Interventing Terhadap Minat Kunjungan Ulang Wisatawan. Jurnal Penelitian Manajemen, 1(2), 144-156. file:///C:/Users/Perpus ～STIE/Downloads/294-Article ～Text-848-1-1020200611.pdf

Mulyati, Y., \& Afrinata, M. (2018). Analisis Pengaruh Strategi Bauran Pemasaran Terhadap Minat Berkunjung Kembali Pada Destinasi Wisata Pantai Carocok Painan Kabupaten Pesisir Selatan (Studi Kasus Pada Wisatawan Domestik). JURNAL AKUNTANSI, EKONOMI Dan MANAJEMEN BISNIS, 6(2), 191-200. https:// doi.org/10.30871/jaemb.v6i2.1014

Mustaqim, O. (2014). Pengaruh Pengawasan Terhadap Kesejahteraan Pedagang Kaki Lima Pada Dinas Pemberdayaan Masyarakat, Pasar, Koperasi Dan Usaha Kecil Menengah Kota Batam. Bening, (1), 1-15. http://dx.doi.org/10.1016/j.biochi.2015.03.025\%0Ahttp://dx.doi.org/10.1038/nat ure10402\%0Ahttp://dx.doi.org/10.1038/nature21059\%0Ahttp://journal.stainkud us.ac.id/index.php/equilibrium/article/view/1268/1127\%0Ahttp://dx.doi.org/ 10.1038/nrmicro2577\%0Ahttp://

Nabila, A. D. (amira. dzatin. n@ugm. ac. id., \& Widiyastuti, D. (dwidiyastuti@ugm. ac. id. (2017). Kajian Atraksi, Amenitas dan Aksesibilitas untuk Pengembangan Pariwisata Umbul Ponggok di Kabupaten Klaten. http:/ /library1.nida.ac.th/termpaper6/sd/2554/19755.pdf

Nguyen Viet, B., Dang, H. P., \& Nguyen, H. H. (2020). Revisit intention and satisfaction: The role of destination image, perceived risk, and cultural contact. Cogent Business and Management, 7(1). https:// doi.org/10.1080/23311975.2020.1796249

Nuraen, B. S. (2013). Analisis Faktor-Faktor Yang Mempengaruhi Minat Kunjung Ulang Wisatawan Museum Ranggawarsita Semarang.

Parastiwi, F. D., \& Farida, N. (2018). Pengaruh Daya Tarik Dan Word-of-Mouth Terhadap Kunjungan Ulang Melalui Kepuasan. Jurnal Administrasi Bisnis, 6(2), 72. https://doi.org/10.14710/jab.v6i2.16608

Pujiyati, H., \& Sukaatmadja, I. P. G. (2020). Anteseden Minat Berkunjung Kembali Wisatawan Spiritual Di Bali (The Antecedent Of Spiritual Tourist Revisit Intention In Bali). E-Jurnal Manajemen Universitas Udayana, 9(1), 21. https:// doi.org/10.24843/ejmunud.2020.v09.i01.p02

Purnami, N. N. A., Suryawardani, I. O., \& Suamba, I. K. (2019). Pengaruh Kualitas Layanan terhadap Kepuasan Pengunjung Agrowisata Bali Pulina untuk Membentuk Minat Kunjungan Ulang. Jurnal Agribisnis Dan Agrowisata (Journal of Agribusiness and Agritourism), 8(1), 59. https://doi.org/10.24843/jaa.2019.v08.i01.p07

Rambe, O. I. (2014). Pengaruh Bauran Pemasaran Jasa Terhadap Minat Berkunjung Kembali Ke Wonders Water World Waterpark Cbd Polonia Medan. Universitas Sumatera Utara.

jmm.unram.ac.id 
Ramli, A. (2020). Strategi Penerapan Konsep Sustainable Tourism di Desa Wisata Sesaot Kecamatan Narmada Lombok Barat Ahmad. Elastisitas, 2(2).

Ratnasari, A. D., \& Harti, H. (2016). Pengaruh Kualitas Produk, Harga, Lokasi, Dan Kualitas Layanan Terhadap Keputusan Pembelian Di Djawi Lanbistro Coffee and Resto Surabaya. Jurnal Pendidikan Tata Niaga (JPTN), 3(3).

Saputro, W. E., Sukimin, \& Indriastuty, N. (2020). Analisis Daya Tarik Wisata, Persepsi Harga, Dan Kualitas Pelayanan Terhadap Minat Berkunjung Ulang Dengan Kepuasan Konsumen Sebagai Variabel Intervening. Jurnal GeoEkonomi, 11(2020), 5673.

Sekaran, U., \& Bougie, R. (2016). Research Methods for Business (Seventh ed). John Wiley \& Sons Ltd. All. www.wileypluslearningspace.com

Soleimani, A. G., Einolahzadeh, H., Gholipour Soleimani, A., \& Einolahzadeh, H. (2018). The influence of service quality on revisit intention: The mediating role of WOM and satisfaction (Case study: Guilan travel agencies). Cogent Social Sciences, 4(1), 1-14. https://doi.org/10.1080/23311886.2018.1560651

Sopyan. (2015). Analisi Pengaruh Daya Tarik Wisata dan Kualitas Pelayanan Terhadap Minat Berkunjung Ulang Pengunjung dengan Kepuasan Pengunjung sebagai Variabel Intervening (Studi pada Cagar Budaya Gedung Lawang Sewu). Universitas Diponegoro Semarang, 1(1), 62.

Sulastri, A., Rapini, T., \& Kristiyana, N. (2018). Analisis Pengaruh Daya Tarik, Kualitas Pelayanan Terhadap Minat Berkunjung Ulang Pengunjung Yang Berkunjung Di Mojosemi Forest Park Kabupaten Magetan Dengan Kepuasan Pengunjung Sebagai Variabel Intervening. Isoquant, 2(1).

Sulistyan, R. B., Ariyono, K. Y., \& Taufiq, M. (2019). IDENTIFIKASI FAKTOR-FAKTOR KRITIS DALAM MINAT BERKUNJUNG KEMBALI KE WISATA RELIGI. Seminar Nasional Manajemen Dan Bisnis Ke-3 Program Studi Manajemen Fakultas Ekonomi Dan Bisnis Universitas Jember.

Widiyanto, I. (2015). Anteseden Minat Berkunjung Ulang (Studi pada Cagar Budaya Bedung Lawang Sewu Semarang). Journal of Management, 4(1), 1-9.

Wirapraja, A., Sudarso, A., Mardia, M., Tojiri, M. Y., Simarmata, H. M. P., Sulasih, S., Permadi, L. A., Purba, B., Dwidienawati, D., Darwin, T., Lie, F., \& Manullang, S. O. (2021). Manajemen Pemasaran Perusahaan. In R. Watrianthos (Ed.), Yayasan Kita Menulis (1st ed., Vol. 1, Issue 1). Yayasan Kita Menulis.

Yusendra, M. A. E., \& Paramitasari, N. (2018). Identifying Factors Affecting Domestic Tourist Satisfaction of Tourist Destinations in Indonesia. DeReMa (Development Research of $\begin{array}{llll}\text { Management): } \quad J u r n a l & \text { Manajemen, }\end{array}$ https://doi.org/10.19166/derema.v13i2.792 